\title{
Species richness of pteridophytes in a montane Atlantic rain forest plot of Southern Brazil ${ }^{1}$
}

\author{
Vinícius Antonio de Oliveira Dittrich ${ }^{2,5}$, Jorge Luiz Waechter ${ }^{3}$ and Alexandre Salino ${ }^{4}$
}

Received: January 07, 2004. Accepted: December 07, 2004

\begin{abstract}
RESUMO - (Riqueza específica de pteridófitas em uma área de Floresta Ombrófila Densa montana no Sul do Brasil). Um inventário florístico de pteridófitas (samambaias e grupos aparentados) foi realizado em uma área de 1ha (100×100 m) no Parque Estadual Pico do Marumbi, município de Morretes, Estado do Paraná, Brasil. A área de estudo é coberta por Floresta Ombrófila Densa Montana e situa-se a aproximadamente $630 \mathrm{~m}$ de altitude. Todas as espécies e formas de vida de pteridófitas ocorrentes no interior da área foram registradas e a maioria foi coletada para determinação específica. No total, 81 espécies pertencentes a 17 famílias foram registradas. As famílias mais ricas foram Polypodiaceae (12 espécies), Hymenophyllaceae (11) e Lomariopsidaceae (11). Os gêneros mais ricos foram Asplenium (dez espécies), Elaphoglossum (dez) e Trichomanes (seis). A composição por forma de vida foi: epífitas (49 espécies), terrícolas (28), rupícolas (duas), epífitas/terrícolas/rupícolas (uma) e epífitas/rupícolas (uma). Nenhuma hemiepífita foi encontrada. As plantas terrícolas incluíram espécies herbáceas (22), arborescentes (quatro) e escandentes (duas). A riqueza da área pode ser considerada elevada quando comparada a outras áreas neotropicais.
\end{abstract}

Palavras-chave: Pteridophyta, diversidade, contagem de espécies, florística, Sul do Brasil

\begin{abstract}
Species richness of pteridophytes in a montane Atlantic rain forest plot of Southern Brazil). A floristic survey of pteridophytes (ferns and fern allies) was carried out in a 1ha plot in the Pico do Marumbi State Park, Morretes, State of Paraná, Southern Brazil. The study area is covered with a closed ombrophilous forest (Brazilian Atlantic Forest) and lies approximately $630 \mathrm{~m}$ in elevation. All species and life-forms of pteridophytes growing in the plot were registered and most of them were collected for taxonomic identification. A total of 81 species, belonging to 17 families were registered. The richest were Polypodiaceae (12 species), Hymenophyllaceae (11) and Lomariopsidaceae (11). The richest genera were Asplenium (ten species), Elaphoglossum (10) and Trichomanes (six). Life-form composition was: epiphytes (49 species), terrestrials (28), lithophytes (two), epiphytes/terrestrials/lithophytes (one) and epiphytes/lithophytes (one). No hemiepiphytes were found. Terrestrials included herbaceous (22 species), arborescent (four) and climbing (two). Species richness of the plot can be considered as high when compared to other neotropical sites.
\end{abstract}

Key words: Pteridophyta, diversity, species count, floristics, Southern Brazil

\section{Introduction}

Several pteridophytes species counts in tropical forests have been conducted in the last few years, using various methods (Whitmore et al. 1985; Young \& León 1989; Tuomisto \& Ruokolainen 1994; Poulsen \& Nielsen 1995; Parris 1996; Poulsen 1996; Galeano et al. 1998; Kessler 2001). The first study attempting to include all pteridophyte species in a 1 ha plot was that of Poulsen \& Nielsen (1995), carried out in the Ecuadorian Amazon. Since then, no further studies have been published for tropical forests.
Young \& León (1989) sampled an area of approximately 2 ha and found 61 species of ferns and fern allies. Whitmore et al. (1985) founded 21 species of ferns in a 0.01 ha plot. Tuomisto \& Ruokolainen (1994) found 35 and 36 species, respectively, in two transect plots of 0.35 ha up to $2 \mathrm{~m}$ above the ground. Poulsen (1996), in Borneo Island, found 21 species of terrestrial pteridophytes (including climbers) in a square 1 ha plot. Parris (1996) sampled various transect plots of 0.5 ha in Malaysia and New Zealand and one plot in Malesia presented 96 species of pteridophytes. Galeano et al. (1998) have found 78 species of pteridophytes in

\footnotetext{
Part of the Master Thesis of the first Author

2 Universidade Estadual Paulista Julio de Mesquita Filho, Instituto de Biociências, Departamento de Botânica, Campus de Rio Claro, Av. 24A, 1515, C. Postal 199, CEP 13500-900, Rio Claro, SP, Brasil

3 Universidade Federal do Rio Grande do Sul, Departamento de Botânica, Av. Bento Gonçalves, 9500, CEP 91570-900, Porto Alegre, RS, Brasil (jorgew@brturbo.com)

4 Universidade Federal de Minas Gerais, Instituto de Ciências Biológicas, Departamento de Botânica, C. Postal 486, CEP 30123-970, Belo Horizonte, MG, Brasil (salino@icb.ufmg.br)

5 Corresponding Author: vinarc@ig.com.br, vinarc@gmail.com
} 
two 0.4 ha transects plus 10 transects of 0.01 ha in the Colombian Chocó area. In much larger areas, a further number of non-quantitative inventories have been carried out (Bueno \& Senna 1992; Salino 1996; Senna \& Waechter 1997; Sylvestre 1997; Labiak \& Prado 1998; Salino \& Joly 2001; Melo \& Salino 2002). Our goal in this study was to conduct a qualitative floristic inventory of all pteridophytes in a 1ha plot in the South Brazilian Atlantic rain forest.

\section{Material and methods}

The Pico do Marumbi State Park (Parque Estadual Pico do Marumbi) is a conservation unit administrated by the Paraná Environmental Institute (Instituto Ambiental do Paraná). It was created in 1990 and covers an area of 2,342 ha (SEMA/IAP 1996).

A 1 ha plot was established, located at ca. $630 \mathrm{~m}$ in elevation in the Pico do Marumbi State Park, Morretes, Paraná State, Southern Brazil (2526'34', S, $48^{\circ} 55^{\prime} 33^{\prime}$ ' $\left.\mathrm{W}\right)$. The area lies on the eastern slope of the "Serra do Mar" mountain range. The vegetation type of the area is the Dense Montane Ombrophilous Forest (Montane Atlantic Forest), following the system proposed by Veloso et al. (1991), or Brazilian Atlantic Forest. The canopy is relatively high, 20-25 m, and epiphytes present a high species richness and abundance.

Mean annual rainfall at the Véu de Noiva meteorological station $(2.55 \mathrm{~km}$ far from the plot, $25^{\circ} 26^{\prime} \mathrm{S}, 48^{\circ} 57^{\prime} \mathrm{W}, 680 \mathrm{~m}$ in elevation) is $3,601.6 \mathrm{~mm}$. The wettest season is from September to March (monthly mean: $377.34 \mathrm{~mm}$ ) with a less humid one from April to August (monthly mean: $194.39 \mathrm{~mm}$ ). In the driest season there is no water deficit. The mean air humidity of the municipality of Paranaguá (approximately $42 \mathrm{~km} \mathrm{E}$ of the plot, at sea-level) is $85 \%$ and in the municipality of Curitiba (approximately $32 \mathrm{~km}$ to the W, $908 \mathrm{~m}$ in elevation) is $82 \%$. It is believed that humidity is even higher at the study site probably due to orographic rains and constant fog (personal observation). The mean annual temperature, calculated according to Maack's formula (Maack 1968), is $18.1^{\circ} \mathrm{C}$. There are no data on temperature at this altitude, only at $908 \mathrm{~m}\left(16.5^{\circ} \mathrm{C}\right.$, Curitiba) and at sea-level (21.1 ${ }^{\circ} \mathrm{C}$, Paranaguá).

The plot, a square hectare, was established avoiding major tree fall gaps, but was impossible to avoid the streams and one crosses the study area. According to Canali \& Fiori (1987), the drainage network is dense at the plot locality. The relief is mountainous and, accordingly, the square 1ha plot was established on a steep slope. The difference between the highest and lowest points was ca. $40 \mathrm{~m}$ and, because of this inclination, the plot presented actually a slightly larger surface.

From August 1998 to February 1999 all species of pteridophytes growing in the plot, including all epiphytes growing on trees rooted inside the plot, were registered and most of them were collected for taxonomic identification (plants collected by Carina Kozera between January 1999 and February 2000 and not collected by the senior author were also cited in the list of species). Epiphytic species were collected with the aid of climbing equipment and binoculars were used to look for epiphytes in the upper canopy. Some species could not be collected, although easily identified, as Cheiroglossa palmata (Ophioglossaceae). Material of species that were not found fertile has not been deposited in herbaria. Voucher material was deposited in the ICN and some material at the UPCB, MBM, UEC, BHCB, GUA and RBR (acronyms according to Holmgren et al. 1990). Names of species' authors follow Brummitt \& Powell (1992). The families were arranged according to the scheme of Moran (1995).

The life-form classification adopted here is: tree ferns, selective terrestrials, facultative terrestrials, holoepiphytes, facultative epiphytes, accidental epiphytes, selective lithophytes, facultative lithophytes, and terrestrial climbers (excluding hemiepiphytes).

\section{Results and discussion}

Eighty one pteridophyte species were recorded in the plot. The richest families were Polypodiaceae (12 species), Hymenophyllaceae (11) and Lomariopsidaceae (11), while the richest genera were Asplenium (10 species), Elaphoglossum (10), and Trichomanes (six), all of them with more epiphytic than non-epiphytic species (Tab. 1). Epiphytes were the life-form with the highest species richness (51), the majority growing as holoepiphytes (47), followed by terrestrials (26), including four arborescent species.

The species richness of this study is the highest recorded for a square hectare plot in the neotropics. This high species richness may be a consequence of the presence of a stream crossing the plot. However, in an area with constant rainfall and a dense drainage network (Canali \& Fiori 1987), it is almost impossible to sample one square hectare without streams. Only in the Old World tropics is this species richness surpassed (Parris 1996), but in a larger area. Even 
Table 1. Species composition of ferns and fern allies in a one hectare plot of montane Atlantic rain forest at Parque Estadual Pico do Marumbi, Paraná, Southern Brazil. Life-forms are classified as tree fern (TF), selective terrestrial (ST), facultative terrestrial (FT), holoepiphyte (HE), facultative epiphyte (FE), accidental epiphyte (AE), selective lithophyte (SL), facultative lithophyte (FL) and terrestrial climber (TC). The voucher number is from the senior author, except when stated. Absence of this number indicates that no botanic material was obtained from the studied area. Complete names of collectors: Marília Borgo, Cláudia Giongo, Maria do Carmo Oliveira Jorge, Carina Kozera, Paulo Henrique Labiak and Olga Kozera.

\begin{tabular}{|c|c|c|}
\hline Class/Family/Species & Life forms & Voucher \\
\hline \multicolumn{3}{|l|}{ LYCOPODIOPSIDA } \\
\hline \multicolumn{3}{|l|}{ LYCOPODIACEAE } \\
\hline Huperzia flexibilis (Fée) B. Øllg. & $\mathrm{HE}$ & $*$ \\
\hline H. heterocarpon (Fée) Holub & $\mathrm{HE}$ & $505 \&$ Jorge $(\mathrm{ICN})$ \\
\hline H. mandiocana (Raddi) Trevis. & $\mathrm{HE}$ & $586 \&$ C. Kozera $(\mathrm{ICN})$ \\
\hline H. cf. quadrifariata (Bory) Rothm. & $\mathrm{HE}$ & $*$ \\
\hline \multicolumn{3}{|l|}{ SELAGINELLACEAE } \\
\hline Selaginella flexuosa Spring & $\mathrm{ST}$ & C. Kozera 1020 \& O. Kozera (UEC) \\
\hline \multicolumn{3}{|l|}{ POLYPODIOPSIDA } \\
\hline \multicolumn{3}{|l|}{ ASPLENIACEAE } \\
\hline Asplenium abscissum Willd. & $\mathrm{ST}$ & 380 et al. (MBM); 506 \& Jorge (ICN) \\
\hline A. feei Kunze ex Fée & $\mathrm{HE}$ & $457(\mathrm{ICN})$ \\
\hline A. incurvatum Fée & $\mathrm{HE}$ & $s . n .(\mathrm{HRCB})$ \\
\hline A. kunzeanum Klotzsch ex Rosenst. & $\mathrm{FT} / \mathrm{FE} / \mathrm{FL}$ & 448 et al. (ICN); 519 (GUA, MBM, RBR) \\
\hline A. mucronatum C. Presl & $\mathrm{HE}$ & $522(\mathrm{ICN})$ \\
\hline A. oligophyllum Kaulf. & $\mathrm{HE}$ & $531(\mathrm{ICN})$ \\
\hline A. raddianum Gaudich. & $\mathrm{HE}$ & 375 (HRCB, RBR); 497 \& Jorge (ICN) \\
\hline A. scandicinum Kaulf. & $\mathrm{HE}$ & 453 et al. (UPCB); 583 (ICN) \\
\hline A. triquetrum N. Murak. \& R.C. Moran & SL & 494 \& Jorge $(\mathrm{ICN})$ \\
\hline Asplenium sp. & $\mathrm{HE}$ & $* *$ \\
\hline \multicolumn{3}{|l|}{ BLECHNACEAE } \\
\hline $\begin{array}{l}\text { Blechnum binervatum (Poiret) C.V. Morton \& Lellinger } \\
\text { subsp. acutum (Desv.) R.M. Tryon \& Stolze }\end{array}$ & $\mathrm{FE}$ & $594 \&$ Jorge $(\mathrm{ICN})$ \\
\hline B. lherminieri (Bory) C. Chr. & ST & $589,595 \&$ C. Kozera $(\mathrm{ICN})$ \\
\hline B. sampaioanum Brade & ST & 381 et al., $592(\mathrm{ICN})$ \\
\hline \multicolumn{3}{|l|}{ CYATHEACEAE } \\
\hline Alsophila sternbergii (Pohl ex Sternb.) D.S. Conant & TF & $588 \&$ Jorge $(\mathrm{ICN})$ \\
\hline Cyathea corcovadensis (Raddi) Domin & TF & C. Kozera 1152 \& Borgo (UEC) \\
\hline C. leucofolis Domin & TF & C. Kozera 1028 \& O. Kozera (UEC) \\
\hline C. phalerata Mart. & TF & 565 (UPCB) \\
\hline \multicolumn{3}{|l|}{ DENNSTAEDTIACEAE } \\
\hline Dennstaedtia dissecta (Sw.) T. Moore & ST & $521(\mathrm{ICN})$ \\
\hline \multicolumn{3}{|l|}{ DRYOPTERIDACEAE } \\
\hline Olfersia cervina (L.) Kunze & ST & $536 \& \operatorname{Labiak}(\mathrm{ICN})$ \\
\hline Polybotrya cylindrica Kaulf. & $\mathrm{TC}$ & 495 \& Jorge (UPCB); 593 et al. (ICN) \\
\hline Rumohra adiantiformis (G. Forst.) Ching & $\mathrm{AE}$ & $555(\mathrm{ICN})$ \\
\hline Stigmatopteris brevinervis (Fée) R.C. Moran & ST & $591(\mathrm{ICN})$ \\
\hline S. caudata (Raddi) C. Chr. & ST & $528(\mathrm{ICN})$ \\
\hline S. heterocarpa (Fée) Rosenst. & ST & 382 et al. (MBM); 535 \& Labiak (ICN) \\
\hline \multicolumn{3}{|l|}{ GRAMMITIDACEAE } \\
\hline Cochlidium punctatum (Raddi) L.E. Bishop & HE & $539 \& \operatorname{Labiak}(\mathrm{ICN})$ \\
\hline Lellingeria schenckii (Hieron.) A.R. Sm. \& R.C. Moran & $\mathrm{HE}$ & $540 \& \operatorname{Labiak}(\mathrm{UPCB}) ; 566$ (ICN) \\
\hline \multicolumn{3}{|l|}{ HYMENOPHYLLACEAE } \\
\hline Hymenophyllum asplenioides (Sw.) Sw. & $\mathrm{HE}$ & $553(\mathrm{ICN})$ \\
\hline H. caudiculatum Mart. & FL & $544 \& \operatorname{Labiak}(\mathrm{ICN})$ \\
\hline H. fragile (Hedw.) C.V. Morton & $\mathrm{HE}$ & $628(\mathrm{ICN})$ \\
\hline H. hirsutum (L.) Sw. & HE & s.n. (HRCB) \\
\hline H. polyanthos $(\mathrm{Sw}.) \mathrm{Sw}$ & $\mathrm{HE}$ & s.n. (HRCB) \\
\hline Trichomanes angustatum Carmich. & $\mathrm{HE}$ & $454(\mathrm{ICN})$ \\
\hline T. diaphanum Kunth & $\mathrm{HE}$ & s.n. (HRCB) \\
\hline T. krausii Hook. \& Grev. & $\mathrm{HE}$ & 496 \& Jorge $(\mathrm{ICN})$ \\
\hline T. pyxidiferum $\mathrm{L}$. & $\mathrm{HE}$ & 451 (UPCB); 517 (ICN) \\
\hline T. radicans $\mathrm{Sw}$. & $\mathrm{HE}$ & 456 (UPCB); 523 (ICN) \\
\hline T. rigidum $\mathrm{Sw}$. & ST & $524(\mathrm{ICN})$ \\
\hline
\end{tabular}


Table 1 (continuation)

\begin{tabular}{|c|c|c|}
\hline Class/Family/Species & Life forms & Voucher \\
\hline \multicolumn{3}{|l|}{ LOMARIOPSIDACEAE } \\
\hline Elaphoglossum cf. angustum (Fée) H. Christ & $\mathrm{HE}$ & $542 \&$ Labiak (ICN) \\
\hline E. bellermanianum (Klotzsch) T. Moore & HE & s.n. $(\mathrm{BHCB})$ \\
\hline E. crassinerve (Kunze) T. Moore & $\mathrm{HE}$ & $*$ \\
\hline E. lingua $($ C. Presl) Brack. & $\mathrm{HE}$ & 552 et al., 570 (ICN) \\
\hline E. cf. nigrescens (Hook.) T. Moore ex Diels & $\mathrm{HE}$ & s.n. (HRCB) \\
\hline E. cf. organense Brade & $\mathrm{HE}$ & $*$ \\
\hline E. ornatum (Mett. ex Kuhn) H. Christ & HE & 379 et al., 452 et al. (UPCB); 526 (ICN) \\
\hline E. strictum (Raddi) T. Moore & $\mathrm{HE}$ & s.n. (BHCB) \\
\hline Elaphoglossum. sp. 1 & $\mathrm{HE}$ & $653(\mathrm{ICN})$ \\
\hline Elaphoglossum. sp. 2 & $\mathrm{HE}$ & $*$ \\
\hline Lomagramma guianensis (Aubl.) Ching & $\mathrm{TC}$ & $568(\mathrm{ICN})$ \\
\hline \multicolumn{3}{|l|}{ MARATTIACEAE } \\
\hline Danaea elliptica $\mathrm{Sm}$. & $\mathrm{ST}$ & C. Kozera $957 \&$ O. Kozera (UEC) \\
\hline D. moritziana C. Presl & $\mathrm{ST}$ & 501 \& Jorge (MBM, UPCB) \\
\hline Marattia raddii Desv. & $\mathrm{ST}$ & $573 \&$ Giongo $; 584$ (MBM, UPCB) \\
\hline \multicolumn{3}{|l|}{ OPHIOGLOSSACEAE } \\
\hline Cheiroglossa palmata (L.) C. Presl & HE & $* *$ \\
\hline \multicolumn{3}{|l|}{ POLYPODIACEAE } \\
\hline Campyloneurum minus Fée & FE/FL & $449(\mathrm{ICN}) ; 561(\mathrm{UPCB})$ \\
\hline C. nitidum (Kaulf.) C. Presl & $\mathrm{HE}$ & $459(\mathrm{ICN}) ; 585$ (UPCB) \\
\hline Microgramma squamulosa (Kaulf.) de la Sota & $\mathrm{HE}$ & s.n. (HRCB) \\
\hline M. tecta (Kaulf.) Alston & HE & $499 \&$ Jorge $(\mathrm{ICN})$ \\
\hline Pecluma recurvata (Kaulf.) M.G. Price & $\mathrm{HE}$ & $556(\mathrm{ICN})$ \\
\hline P. truncorum (Lindm.) M.G. Price & HE & $541 \& \operatorname{Labiak}(\mathrm{ICN})$ \\
\hline Pleopeltis angusta Willd. & $\mathrm{HE}$ & $569(\mathrm{ICN})$ \\
\hline P. astrolepis (Liebm.) E. Fourn. & $\mathrm{HE}$ & $500 \&$ Jorge $(\mathrm{ICN})$ \\
\hline Polypodium catharinae Langsd. \& Fisch. & HE & $532(\mathrm{ICN}) ; 554(\mathrm{UPCB})$ \\
\hline$P$. fraxinifolium Jacq. & $\mathrm{HE}$ & $460(\mathrm{ICN})$ \\
\hline P. hirsutissimum Raddi & $\mathrm{HE}$ & $450(\mathrm{ICN}) ; 564(\mathrm{UPCB})$ \\
\hline P. pleopeltidis Fée & $\mathrm{HE}$ & $507 \&$ Jorge $(\mathrm{ICN})$ \\
\hline \multicolumn{3}{|l|}{ PTERIDACEAE } \\
\hline Pteris decurrens C. Presl & ST & $502 \&$ Jorge, $567(\mathrm{ICN}) ; 530$ (UPCB) \\
\hline \multicolumn{3}{|l|}{ TECTARIACEAE } \\
\hline Ctenitis deflexa (Kaulf.) Copel. & ST & $525(\mathrm{ICN})$ \\
\hline C. pedicellata (H. Christ) Copel. & $\mathrm{ST}$ & 562 (UPCB); 579 (ICN) \\
\hline Lastreopsis amplissima (C. Presl) Tindale & ST & $520(\mathrm{ICN})$ \\
\hline $\begin{array}{l}\text { Megalastrum wacketii (Rosenst. ex C. Chr.) A.R. Sm. \& } \\
\text { R.C. Moran }\end{array}$ & $\mathrm{ST}$ & C. Kozera 1086 \& Borgo (UEC) \\
\hline Tectaria incisa Cav. & ST & C. Kozera 1175 \& O. Kozera (UEC) \\
\hline \multicolumn{3}{|l|}{ VITTARIACEAE } \\
\hline Polytaenium lineatum (Sw.) J. Sm. & $\mathrm{HE}$ & $533 \& \operatorname{Labiak}(\mathrm{ICN})$ \\
\hline Vittaria graminifolia Kaulf. & $\mathrm{HE}$ & 455 (UPCB); 550 \& Jorge (ICN) \\
\hline V. lineata (L.) Sm. & $\mathrm{HE}$ & $534 \& \operatorname{Labiak}(\mathrm{UPCB})$ \\
\hline \multicolumn{3}{|l|}{ WOODSIACEAE } \\
\hline Diplazium ambiguum Raddi & ST & $518(\mathrm{ICN}) ; 529$ (MBM, UPCB) \\
\hline D. cristatum (Desr.) Alston & $\mathrm{ST}$ & $458(\mathrm{UPCB}) ; 538(\mathrm{ICN})$ \\
\hline D. plantaginifolium (L.) Urb. & $\mathrm{ST}$ & $461(\mathrm{ICN})$ \\
\hline
\end{tabular}

* Plants not collected because they were sterile; ** Plants not collected because they were at difficult access places. 
there, the species richness in a square hectare may be lower (the numbers verified by Parris were gathered along transects). This species richness is comparable with a 10,000 times larger and well studied area of tropical forest, like the Ducke Reserve, in the Brazilian Amazon, with 84 species (Costa et al. 1999), although the whole Brazilian Amazon can be considered, actually, a poor area concerning pteridophytes, containing only 279 species according to Tryon \& Conant (1975). As for the holoepiphytes, the same holds true: the species richness (47) is also the highest recorded in the neotropics for a square hectare plot. Even in areas many times larger, like the Volta Velha Reserve ( 1,136 ha), the species richness (49) is similar to this site (Labiak \& Prado 1998). The prevalence of epiphytes in the plot is in accordance with most floristic surveys carried out in tropical rain forests, where high averages of air moisture and rainfall provide a suitable environment. Kornaš (1977) and Godoy (1990) call attention to the prevalence of epiphytes among pteridophytes in areas with high rainfall. Areas with a marked dry season are impoverished in epiphytes (Gentry \& Dodson 1987). This is exemplified by Borgo et al. (2002) and Melo \& Salino (2002), whose studies were carried out in semi-deciduous forests in Southern and Southeastern Brazil respectively. When only the preferentially terrestrial plants are considered, the number of species is again superior to that found in other surveys (Poulsen \& Balslev 1991; Poulsen \& Nielsen 1995; Poulsen 1996). Only in Malesia (Borneo) Poulsen \& Pendry (1995) have found a higher number of ground herbs in a plot of 0.25 ha in a montane rain forest. The main factor influencing the richness of pteridophytes in the plot seems to be the presence of different microhabitats. There are exposed rocks, ravines, and a stream, which possibly contribute, in some extent, to the observed richness. Another factors to be considered are the high and constant rainfall and air humidity. Other areas in Southeastern Brazil not yet inventoried can possibly shelter more species in a similar area. Future studies are needed, since the only another area of tha inventoried for pteridophytes in Brazil presented just 42 species (V.A.O. Dittrich, unpublished data).

Concerning life-forms, Rumohra adiantiformis was considered an accidental epiphyte, because this species, at least in Southern Brazil, is preferentially terrestrial (Labiak \& Prado 1998; Dittrich et al. 1999; Kersten \& Silva 2001; 2002 - but see also Waechter 1998) and only one individual was found in the area, probably by chance growing as an epiphyte. Tryon \&
Tryon (1982) point out that this species is epiphytic in some areas of its geographic distribution and terrestrial in others. Blechnum binervatum subsp. acutum was considered a facultative epiphyte, because young sporophytes were observed on the phorophytes, not connected to soil at any phase of the life cycle, but this is not the rule for this taxon, at least in Southern Brazil, as observed by Waechter (1986), Senna \& Waechter (1997) and Dittrich et al. (1999), who state this taxon is terrestrial or hemiepiphytic. Dislich \& Mantovani (1998) observed a rather indifferent preference for substrate in this subspecies, pointing out that the plants are epiphytes but occasionally hemiepiphytes. We infer that this is a epiphytic or hemiepiphytic subspecies, with some individuals that start their life in soil and fail to find a phorophyte to climb. These terrestrial individuals are almost always sterile. Like in Polybotrya (Moran 1987), apparently Blechnum binervatum subsp. acutum needs to achieve a higher canopy level in the forest to produce fertile fronds. Polybotrya cylindrica was considered as an hemiepiphyte by some authors (Sylvestre 1997; Labiak \& Prado 1998), but we did not observe any plant lacking contact with the soil, consequently the species was considered a climber. Hymenophyllum caudiculatum is frequently found as an epiphytic plant (Labiak \& Prado 1998), but can be observed as a lithophyte (pers. obs.; A. Salino, not published) or even as a terrestrial plant (A. Salino, not published). The only specimen growing in the plot was a lithophyte. Because of this, that taxon was considered as a facultative lithophyte. Asplenium triquetrum seems to be an obligate lithophyte preferentially near or at streams, as pointed out by Murakami \& Moran (1993). Alsophila sternbergii shows a clear preference for areas near the stream. Diplazium plantaginifolium, Selaginella flexuosa and Trichomanes rigidum only grow along stream banks. Pecluma truncorum and Asplenium mucronatum grow only and preferentially on tree ferns respectively, as has been pointed out by Evans (1969) for Pecluma and L.S. Sylvestre (unpublished data) for Asplenium. Moran et al. (2003) have found seven species, out of 106 , growing exclusively on tree ferns, and four additional species dwelling preferentially on tree ferns in Costa Rica, three of which were of the same genera found here, but of different species.

Making floristic comparisons is difficult, because there is only one other survey of pteridophytes in a one square hectare in Brazil (V.A.O. Dittrich, unpublished data). Other studies are in much larger areas and do not always inventorying all life-forms 
(Labiak \& Prado 1998). Besides this, in many studies, all the plants growing in large areas, containing various vegetation types, were collected, making any comparison difficult and relatively misleading.

Concerning the distribution of the plants inside the plot, some species, e.g. Alsophila sternbergii, were fairly common and possessed many individuals inside the plot. On the other hand, in some species only one individual was observed, e.g. Asplenium sp. and Cheiroglossa palmata. The last species is rare in nature, as indicated by the low number of specimens in herbaria. Stigmatopteris heterocarpa was gregariously distributed, possibly indicating response to some variation in soil properties. The correspondence between pteridophytes and different types of soils is well documented (Tuomisto \& Poulsen 1996).

This study highlights the importance of conservation of what remains of the Brazilian Atlantic Forest, one of the biodiversity hotspots of Myers et al. (2000) that must receive continued efforts for its protection.

\section{Acknowledgements}

We thanks to CAPES (Coordenação de Aperfeiçoamento do Pessoal de Ensino Superior) for the fellowship to the senior author; to UFRGS (Universidade Federal do Rio Grande do Sul), and to UFPR (Universidade Federal do Paraná), for providing facilities. We also thank to Dr. Sandro Menezes Silva for helping in many ways, Dr. Lana da Silva Sylvestre for aid with the genus Asplenium, Dr. Reinaldo Monteiro, for the English revision, to Dr. Harold G. Fowler, for the final English revision, and to Dr. Axel D. Poulsen, for sending useful literature and making suggestions on the manuscript. Finally, we thank to Carina Kozera, Claudia Giongo, Maria do Carmo Oliveira Jorge, Marília Borgo, Miriam Kaehler, Paulo Labiak and Vera Dittrich for help during field work.

\section{References}

Borgo, M.; Silva, S.M. \& Petean, M.P. 2002. Epífitos vasculares em um remanescente de Floresta Estacional Semidecidual, município de Fênix, PR, Brasil. Acta Biologica Leopoldensia 24(2): 121-130.

Brummitt, R.K. \& Powell, C.E. 1992. Authors of plant names. Kew, Royal Botanic Gardens.

Bueno, R.M. \& Senna, R.M. 1992. Pteridófitas do Parque Nacional dos Aparados da Serra I. Região do Paradouro. Caderno de Pesquisa, Série Botânica 4(1): 5-12.
Canali, N.E. \& Fiori, C.O. 1987. Análise morfométrica da rede de drenagem da área do Parque Marumbi - Serra do Mar (PR). Pp. 21-40. In: Atas do III Simpósio Sul-brasileiro de Geologia. Curitiba 1987. V. I.

Costa, M.A.S.; Prado, J.; Windisch, P.G.; Freitas, C.A.A. \& Labiak, P.H. 1999. Pteridophyta. Pp. 97-117. In: J.E.L.S. Ribeiro; M. Hopkins; A. Vicentini; C. Sothers; M.A. Brito; M.A. Souza; L.H. Martins; L.G. Lohmann; P.A. Assunção; E. Pereira; C.F. Silva; M.R. Mesquita \& L. Procópio (eds.). Flora da Reserva Ducke. Guia de identificação das plantas vasculares de uma floresta de terra-firme na Amazônia Central. Manaus, INPA.

Dislich, R. \& Mantovani, W. 1998. A flora de epífitas vasculares da Reserva da Cidade Universitária "Armando de Salles Oliveira" (São Paulo, Brasil). Boletim de Botânica da Universidade de São Paulo 17: 61-83.

Dittrich, V.A.O.; Kozera, C. \& Menezes-Silva, S. 1999. Levantamento florístico dos epífitos vasculares do Parque Barigüi, Curitiba, Paraná, Brasil. Iheringia, Série Botânica 52: 11-21.

Evans, A.M. 1969. Interspecific relationships in the Polypodium pectinatum-plumula complex. Annals of the Missouri Botanical Garden 55(3): 193-293.

Galeano, G.; Suárez, S. \& Balslev, H. 1998. Vascular plant species count in a wet forest in the Chocó area on the Pacific coast of Colombia. Biodiversity \& Conservation 7(12): 1563-1575.

Gentry, A.H. \& Dodson, C.H. 1987. Diversity and biogeography of neotropical vascular epiphytes. Annals of the Missouri Botanical Garden 74(2): 205-233.

Godoy, R. 1990. Espectro biológico de la flora pteridofítica de Chile continental e insular. Anales del Jardín Botánico de Madrid 46(2): 599-603.

Holmgren, P.K.; Holmgren, N.H. \& Barnett, L.C. 1990. Index Herbariorum. Part I. The herbaria of the world. $8^{\text {th }} \mathrm{Ed}$., New York, The New York Botanical Garden.

Kersten, R.A. \& Silva, S.M. 2001. Composição florística e estrutura do componente epifítico vascular em floresta da planície litorânea na Ilha do Mel, Paraná, Brasil. Revista Brasileira de Botânica 24(2): 213-226.

Kersten, R.A. \& Silva, S.M. 2002. Composição florística e estrutura do componente epifítico vascular em floresta mista aluvial do Rio Barigüi, Paraná, Brasil. Revista Brasileira de Botânica 25(3): 259-267.

Kessler, M. 2001. Pteridophyte species richness in Andean forests in Bolivia. Biodiversity and Conservation 10(9): 1473-1495.

Kornaš, J. 1977. Life-forms and seasonal patterns in the pteridophytes in Zambia. Acta Societatis Botanicorum Poloniae 46(4): 669-690.

Labiak, P.H. \& Prado, J. 1998. Pteridófitas epífitas da Reserva Volta Velha, Itapoá - Santa Catarina, Brasil. Boletim do Instituto de Botânica 11: 1-79.

Maack, R. 1968. Geografia física do Estado do Paraná. Rio de Janeiro, José Olympio.

Melo, L.C.N. \& Salino, A. 2002. Pteridófitas de duas áreas de floresta da Bacia do Rio Doce no estado de Minas Gerais, Brasil. Lundiana 3(2): 129-139. 
Moran, R.C. 1987. Monograph of the Neotropical fern genus Polybotrya (Dryopteridaceae). Illinois Natural History Survey Bulletin 34: 1-138.

Moran, R.C. 1995. Clave para las familias de pteridófitas. Pp. 1-2. In: G. Davidse; M.S. Souza \& S. Knapp (eds.). Flora Mesoamericana. Vol. I. Psilotaceae a Salviniaceae. México, Universidad Nacional Autónoma de México, DF.

Moran, R.C.; Klimas, S. \& Carlsen, M. 2003. Low-trunk epiphytic ferns on tree ferns versus angiosperms in Costa Rica. Biotropica 35(1): 48-56.

Murakami, N. \& Moran, R.C. 1993. Monograph of the Neotropical species of Asplenium sect. Hymenasplenium (Aspleniaceae). Annals of the Missouri Botanical Garden 80(1): 1-38.

Myers, N.; Mittermeier, R.A.; Mittermeier, C.G.; Fonseca, G. A.B. \& Kent, J. 2000. Biodiversity hotspots for conservation priorities. Nature 403(6772): 853-858.

Parris, B.S. 1996. Measurements of pteridophyte species diversity in Malesia and New Zealand. Pp. 43-51. In: J.M. Camus; M. Gibby \& R.J. Johns (eds.). Pteridology in perspective. Kew, Royal Botanic Gardens.

Poulsen, A.D. 1996. Species richness and density of ground herbs within a plot of lowland rainforest in north-west Borneo. Journal of Tropical Ecology 12(2): 177-190.

Poulsen, A.D. \& Balslev, H. 1991. Abundance and cover of ground herbs in an Amazonia rain forest. Journal of Vegetation Science 2(3): 315-322.

Poulsen, A.D. \& Nielsen, I.H. 1995. How many ferns are there in one hectare of tropical rain forest ? American Fern Journal 85(1): 29-35.

Poulsen A.D. \& Pendry, C.A. 1995. Inventories of ground herbs at three altitudes on Bukit Belalong, Brunei, Borneo. Biodiversity and Conservation 4(7): 745-757.

Salino, A. 1996. Levantamento das pteridófitas da Serra do Cuscuzeiro, Analândia, SP, Brasil. Revista Brasileira de Botânica 19(2): 173-178.

Salino, A. \& Joly, C.A. 2001. Pteridophytes of three remnants of gallery forests in the Jacaré-Pepira river basin, São Paulo State, Brazil. Boletim do Herbário Ezechias Paulo Heringer 8: 5-15.
SEMA/IAP. 1996. Plano de manejo do Parque Estadual Pico do Marumbi - PR. Curitiba, Secretaria de Estado do Meio Ambiente/Instituto Ambiental do Paraná.

Senna, R.M. \& Waechter, J.L. 1997. Pteridófitas de uma floresta com araucária. I. Formas biológicas e padrões de distribuição geográfica. Iheringia, Série Botânica 48: 41-58.

Sylvestre, L.S. 1997. Pteridófitas da Reserva Ecológica de Macaé de Cima. Pp. 41-52. In: H.C. Lima \& R.R. GuedesBruni (eds.). Serra de Macaé de Cima: diversidade florística e conservação em mata atlântica. Rio de Janeiro, Jardim Botânico do Rio de Janeiro.

Tryon, R.M. \& Conant, D.S. 1975. The ferns of Brazilian Amazonia. Acta Amazonica 5(1): 23-34.

Tryon, R.M. \& Tryon, A.F. 1982. Ferns and allied plants, with special reference to tropical America. New York, Springer-Verlag.

Tuomisto, H. \& Poulsen, A.D. 1996. Influence of edaphic specialization on pteridophyte distribution in neotropical rain forests. Journal of Biogeography 23(3): 283-293.

Tuomisto, H. \& Ruokolainen, K. 1994. Distribution of Pteridophyta and Melastomataceae along an edaphic gradient in an Amazonian rain forest. Journal of Vegetation Science 5(1): 25-34.

Veloso, H.P.; Rangel Filho, A.L.R. \& Lima, J.C.A. 1991. Classificação da vegetação brasileira, adaptada a um sistema universal. Rio de Janeiro, IBGE.

Waechter, J.L. 1986. Epífitos vasculares da Mata Paludosa do Faxinal, Torres, Rio Grande do Sul, Brasil. Iheringia, Série Botânica 34: 39-49.

Waechter, J.L. 1998. Epifitismo vascular em uma floresta de restinga do Brasil subtropical. Revista Ciência e Natura 20: $43-66$.

Whitmore, T.C.; Peralta, R. \& Brown, K. 1985. Total species count in a Costa Rican rain forest. Journal of Tropical Ecology 1(4): 375-378.

Young, K.R. \& León, B. 1989. Pteridophyte species diversity in the central Peruvian Amazon: importance of edaphic specialization. Brittonia 41(4): 388-395. 